Acta vet. scand. $1984,25,242-249$.

From the Department of Food Hygiene, Faculty of Veterinary Medicine, Swedish University of Agricultural Sciences, Uppsala, Sweden.

\title{
PREVALENCE OF ENTEROTOXIGENIC STAPHYLOCOCCI IN NOSE, THROAT AND SKIN LESIONS IN MEAT-WORKERS
}

\author{
By \\ Marie-Louise Danielsson and Bo Hellberg
}

\begin{abstract}
DANIELSSON, MARIE-LOUISE and BO HELLBERG: Prevalence of enterotoxigenic staphylococci in nose, throat and skin lesions in meat-workers. Acta vet. scand. 1984, 25, 242-249. - The frequency of enterotoxigenic coagulase-positive and coagulase-negative staphylococci in nose and throat and in hand lesions was investigated in 86 meat cutters and dressers. Enterotoxin-producing staphylococci were demonstrated in nasal swabs from $22 \%$ of clinically well workers and from $42 \%$ of a group with mild coryza. The corresponding rates in throat swabs were 6 and $12 \%$. Four of 16 superficial lesions of the hand harbored enterotoxigenic staphylococci. The implications for contamination of food and outbreaks of staphylococcal food poisoning are discussed.
\end{abstract}

food poisoning; contamination; slaughter hygiene; microbial flora; public health.

Staphylococci have a wide environmental distribution and occur frequently on the skin and in the upper respiratory tract of man and animals. Many staphylococcal strains vegetate harmlessly on skin and mucous membranes, but potentially pathogenic strains can cause a wide range of infections, such as abscesses, meningitis, osteomyelitis, pyemia and suppuration of wounds. Certain strains, moreover, may cause food poisoning. The first recorded outbreak of staphylococcal food poisoning, in which 300 persons fell ill after eating Cheddar cheese, was described by Vaughn in 1884. Upon ingestion of a substance extracted from the cheese, Vaughn experienced the same symptoms as in the patients. Microscopy of the cheese revealed spherical microorganisms and it was concluded that a poison produced by these bacteria was responsible for the symptoms. 
Nowadays it is recognized that staphylococcal food poisoning is caused by enterotoxins produced by certain strains of staphylococci. Seven enterotoxins $\left(A, B, C_{1}, C_{2}, D, E\right.$ and $F$ ) have hitherto been purified and identified (Casman 1960, Bergdoll et al. 1965, 1967, 1971, 1981, Avena \& Bergdoll 1967, Borja \& Bergdoll 1967, Casman et al. 1967).

Staphylococci are known to multiply even under seemingly unfavorable environmental conditions, e.g. in $15 \%$ saline solution (Buchanan \& Gibbons 1974). The production of staphylococcal enterotoxins also is fairly insensitive to the environmental influence. Thus, enterotoxin may be generated in the $\mathrm{pH}$ range 4.0-9.8 (Genigeorgis et al. 1971), in $10 \%$ saline solution (McLean et al. 1968) and at temperatures of $13-45^{\circ} \mathrm{C}$ (Scheusner et al. 1973). Most common foodstuffs therefore are suitable media for the growth of enterotoxigenic staphylococci and production of enterotoxin.

Handling of food can provide ample opportunities for contamination with staphylococci of human origin. The aims of the present study therefore were:

1. to calculate the frequency of staphylococci in the nose, throat and skin lesions of workers in the meat industry, and

2. to investigate the enterotoxin-producing ability of the isolated strains.

\section{MATERIAL AND METHODS}

\section{Isolation and identification}

Samples were taken from 86 workers in different meatdressing plants. They were classified as clinically healthy (37 persons), having mild coryzal symptoms ( 33 persons) and noncoryzal but with minor skin lesions on the hands (16 persons). From each subject, swab samples were taken from the nose (vestibulum nasi) and throat. When appropriate, swabs were also taken from hand lesions. Altogether 188 specimens were collected -86 from nose, 86 from throat and 16 from skin. Each specimen was placed in a separate sterile glass tube and immediately transported to the laboratory. The specimens were cultured on Blood Agar Base (Oxoid, England) supplemented with $5 \%$ sterile, defibrinated bovine blood and incubated at $37^{\circ} \mathrm{C}$ for 24 and $48 \mathrm{~h}$.

Based on colony appearance and cell morphology, 5 suspected staphylococcal colonies were isolated from each agar plate. All 
gram-positive, spherical cells which were catalase-positive and fermented and oxidated glucose were regarded as staphylococci (Recommendations 1965, Buchanan \& Gibbons 1974). In addition, the strains were tested for coagulase activity in rabbit plasma. When staphylococci were isolated from more than 1 sampling site in the same person, the strains were tested for hemolysin production (bovine erythrocytes), DNase activity, aerobic acid from mannitol and appearance on ETGP (egg yolk tellurite glycine pyruvate) agar (Baird-Parker 1962).

\section{Enterotoxin production}

The strains were tested for production of enterotoxins A, B and $\mathrm{C}_{1}$, using antisera and reference enterotoxins from Serva Feinbiochemica (Heidelberg, Germany). In order to obtain a concentrated enterotoxin solution, the 'cellophane sac culture technique' described by Donnelly et al. 1967 was used. The enterotoxins were determined serologically, using Wadsworth's (1957) miniaturization of the gel double-diffusion test according to Ouchterlony (1949). The test was performed as described by Crowle (1958) and Zehren \& Zehren (1968).

\section{RESULTS}

The results of the investigation are surveyed in Tables 1 and 2. Since both Staphylococcus aureus and S. epidermidis can produce enterotoxin, we have not distinguished between these species in presentation of the results. Altogether 169 staphylococcal strains were isolated. Staphylococci were invariably found in at least one of the three investigated sites. The nose provided the highest number of positive swabs. The frequency of nose swabs showing staphylococci was not significantly different in the apparently healthy persons ( 34 of 37 ) than in those with mild coryzal symptoms (31 of 33 ). The throat likewise gave similar yield of staphylococci in the healthy group and in the mildly coryzal workers (Table 1 ).

By contrast, the frequency of enterotoxin-producing staphylococci in nose swabs was clearly higher in coryzal (42\%) than in well $(22 \%)$ workers (Table 2). The corresponding frequencies from the throat swabs were 12 and $6 \%$. Staphylococci were isolated from 13 of 16 skin lesions and in 4 cases these staphylococci were enterotoxin-producing. 
T a b l e 1. Frequency of staphylococci isolated from meat cutters and dressers.

\begin{tabular}{lcccccccc}
\hline & No of & \multicolumn{6}{c}{ Number of workers with staphylococci in } \\
\cline { 3 - 8 } workers & $\begin{array}{c}\text { nose } \\
\text { only }\end{array}$ & $\begin{array}{c}\text { throat } \\
\text { only }\end{array}$ & $\begin{array}{c}\text { skin le- } \\
\text { sion only }\end{array}$ & $\begin{array}{c}\text { nose }+ \\
\text { throat }\end{array}$ & $\begin{array}{c}\text { nose }+ \\
\text { lesion }\end{array}$ & $\begin{array}{c}\text { throat }+ \\
\text { lesion }\end{array}$ & $\begin{array}{c}\text { nose + throat } \\
\text { + lesion }\end{array}$ \\
\hline $\begin{array}{l}\text { Clinically } \\
\text { well }\end{array}$ & 37 & 25 & 3 & - & 9 & - & - & - \\
$\begin{array}{l}\text { Slightly } \\
\text { coryzal }\end{array}$ & 33 & 22 & 2 & - & 9 & - & - & - \\
$\begin{array}{l}\text { Hand } \\
\text { lesions }\end{array}$ & 16 & - & 1 & - & 2 & 5 & 1 & 7 \\
\hline
\end{tabular}

T a b l e 2. Frequency of enterotoxin-producing staphylococci isolated from meat cutters and dressers.

\begin{tabular}{lcccccccc}
\hline & \begin{tabular}{c}
\multicolumn{6}{c}{ Number of workers with enterotoxigenic staphylococci in } \\
\cline { 3 - 8 } Go of \\
workers
\end{tabular} & $\begin{array}{c}\text { nose } \\
\text { only }\end{array}$ & $\begin{array}{c}\text { throat } \\
\text { only }\end{array}$ & $\begin{array}{c}\text { skin le- } \\
\text { sion only }\end{array}$ & $\begin{array}{c}\text { nose }+ \\
\text { throat }\end{array}$ & $\begin{array}{c}\text { nose }+ \\
\text { lesion }\end{array}$ & $\begin{array}{c}\text { throat }+ \\
\text { lesion }\end{array}$ & $\begin{array}{c}\text { nose + throat } \\
\text { + lesion }\end{array}$ \\
\hline $\begin{array}{l}\text { Clinically } \\
\text { well }\end{array}$ & 37 & 7 & 1 & - & 1 & - & - & - \\
$\begin{array}{l}\text { Slightly } \\
\text { coryzal }\end{array}$ & 33 & 12 & 2 & - & 2 & - & - & - \\
$\begin{array}{l}\text { Hand } \\
\text { lesions }\end{array}$ & 16 & 3 & 1 & 2 & - & 1 & - & 1 \\
\hline
\end{tabular}

Altogether 44 enterotoxin-producing staphylococcal strains were isolated. The dominant enterotoxin type was A (34 of the 44 strains). Enterotoxin $B$ was produced by 4 strains and $C_{1}$ also by 4 strains, while 1 strain produced both $A$ and $C_{1}$ and another both $B$ and $C_{1}$. No relationship was demonstrated between the site from which staphylococci were isolated and the type of enterotoxin they produced. Six of the 44 enterotoxin-producing staphylococcal strains were coagulase-negative ( 3 giving enterotoxin type $A$, and 3 type $C_{1}$ ).

\section{DISCUSSION}

The literature contains few reports concerning enterotoxinproducing staphylococci isolated from healthy persons (Moore $\&$ Bower 1971, Economopoulou 1972, Untermann 1972, Mochmann et al. 1976). These reports, moreover, deal only with Staphylococcus aureus. This is a serious defect, since $\mathrm{S}$. epidermidis also 
can produce enterotoxin and thus cause food poisoning (Omori \& Kato 1959, Bergdoll et al. 1967, Breckinridge \& Bergdoll 1971). In our investigation as many as $14 \%$ of the enterotoxin-producing strains were of epidermidis type. Five of the 6 coagulase-negative enterotoxin-producing strains were isolated from nasal swabs.

Enterotoxigenic staphylococci, coagulase-positive or negative, in the nose can involve high risk of food contamination. The bacteria are readily transferred from nose to hands. If contaminated hands infect foodstuffs, and these are stored for too long at unsuitably high temperature, enterotoxin production may take place, with attendant risk of staphylococcal food poisoning. In the present study, the pronounced increase of swabs showing enterotoxin-producing staphylococci in connection with coryza was particularly alarming.

The skin lesions of the hands were found to harbor enterotoxin-producing staphylococci in 4 of the 16 investigated cases. None of the lesions was suppurating, and they were regarded by the workers as harmless scratches. This type of injury is common in the meat industry, since knives and carcase bones readily damage the hands. Because of the high frequency, sick-listing of workers for such minor trauma is not realistic. What, then, is the risk of food poisoning from handling of raw meat by persons with hand injuries? McCoy (1966) showed that staphylococci do not grow on raw meat unless the surface is free from the micro-organisms normally present there. He also showed that production of enterotoxin is completely inhibited by this microflora. Accordingly, it may be acceptable to permit handling of raw meat despite small lesions of the hands. The available literature contains no reports of staphylococcal food poisoning caused by contaminated raw meat.

On the other hand, precautions should be accentuated in regard to hand lesions in persons working with ready-cooked foods. These products generally have been heat-treated and their normal microflora thereby destroyed. Contamination with enterotoxigenic staphylococci consequently involves a risk of enterotoxin production. Accordingly, staphylococcal food poisoning from 'ready-to eat' dishes infected by organisms from hand wounds is not uncommon (Breckinridge \& Bergdoll 1971, Center for Disease Control 1975) Processed food may be contaminated also by contact with coryzally infected persons. In our study as many as $42 \%$ of the workers with slight colds harbored entero- 
toxigenic staphylococci in the nose. Unless hand hygiene is meticulous, nasal staphylococci are readily transferred to handled food. For persons engaged in food processing, therefore, temporary transfer to work not involving handling of food is recommended during episodes of colds or hand injuries.

\section{ACKNOWLEDGEMENTS}

The authors wish to thank Dr Stefan Rånquist, sanitarian at Enskede slaughterhouse district, for generous help, and Mrs Margareta Lagerberg for skilful technical assistance.

\section{REFERENCES}

Avena, R. M. \& M. S. Bergdoll: Purification and some physico-chemical properties of enterotoxin C, Staphylococcus aureus strain 361 . Biochemistry 1967, 6, 1474-1480.

Baird-Parker, A. C.: An improved diagnostic and selective medium for isolating coagulase positive staphylococci. J. appl. Bact. $1962,25,12-19$.

Bergdoll, M. S., C. R. Borja \& R. M. Avena: Identification of a new enterotoxin as enterotoxin C. J. Bacteriol. 1965, 90, 1481-1485.

Bergdoll, M. S., C. R. Borja, R. Robbins \& K. F. Weiss: Identification of enterotoxin E. Infect. Immun. 1971, 4, 593-595.

Bergdoll, M. S., B. A. Crass, R. F. Reiser, R. N. Robbins \& J. P. Davis: A new staphylococcal enterotoxin, enterotoxin $F$, associated with toxic-shock-syndrome Staphylococcus aureus isolates. Lancet 1981, May 9, 1017-1021.

Bergdoll, M. S., M. J. Surgalla \& G. M. Dack: Staphylococcal enterotoxin. Identification of a specific precipating antibody with enterotoxin-neutralizing property. J. Immunol. 1959, 83, 334338.

Bergdoll, M. S., K.F. Weiss \& M. J. Muster: The production of staphylococcal enterotoxin by a coagulase-negative microorganism. Bact. Proc. 1967, 12.

Buchanan, R. E. \& N. E. Gibbons (eds.): Bergey's Manual of Determinative Bacteriology 8th Ed. The Williams \& Wilkins Company, Baltimore, USA 1974, p. 478-489.

Borja, C. R. \& M. S. Bergdoll: Purification and partial characterization of enterotoxin $\mathrm{C}$ produced by Staphylococcus aureus strain 137. Biochemistry 1967, 6, 1467-1473.

Breckinridge, J. C. \& M. S. Bergdoll: Outbreak of foodborne gastroenteritis due to a coagulase-negative enterotoxin-producing staphylococcus. New Engl. J. Med. 1971, 284, 541-543.

Casman, E. P.: Further serological studies of staphylococcal enterotoxin. J. Bacteriol. 1960, 79, 849-856. 
Casman, E. P., K. W. Bennett, A. E. Dorsey \& J. A. Issa: Identification of a fourth staphylococcal enterotoxin, enterotoxin D. J. Bacteriol. 1967, 94, 1875-1882.

Center for Disease Control: Outbreak of staphylococcal food poisoning aboard an aircraft. Morbidity and Mortality Weekly Report $1975,24,57-59$.

Crowle, A. J.: A simplified micro double-diffusion agar precipitin technique. J. Lab. Clin. Med. 1958, 52, 784-787.

Donnelly, C. B., J. E. Leslie, L. A. Black \& K. H. Lewis: Serological identification of enterotoxigenic staphylococci from cheese. Appl. Microbiol. 1967, 15, 1382-1387.

Economopoulou, C.: Microorganisms in the nose, throat and the intestine. Alimenta 1972, 11, 61-63.

Genigeorgis, C., M. S. Foda, A. Mantis \& W. W. Sadler: Effect of sodium chloride and $\mathrm{pH}$ on enterotoxin $\mathrm{C}$ production. Appl. Microbiol. $1971,21,862-866$.

McCoy, D. W.: Growth and enterotoxin production of enterotoxigenic staphylococci in meats. Diss. Abstr. B. 1966, 27, 1033.

McLean, R. A., H. D. Lilly \& J. A. Alford: Effects of meatcuring salts and temperature on production of staphylococcal enterotoxin $B$. J. Bacteriol. 1968, 95, 1207-1211.

Mochmann, H., U. Richter, W. Karsch, W. Witte \& W. Meyer: Studies of enterotoxin production by strains of Staphylococcus aureus of different origins. Zbl. Bakt. Hyg. I. Abt. Orig. A. 1976, 234, $434-449$.

Moore, J. M. \& R. K. Bower: Serologic, biochemical and cultural traits of enterotoxigenic and coagulase-positive staphylococci isolated from food handlers. HSMHA Health Reports 1971, 86, 815-819.

Omori, G. \& Y. Kato: A staphylococcal food-poisoning caused by a coagulase negative strain. Biken's J. 1959, 2, 92-96.

Ouchterlony, Ö.: Antigen-Antibody Reaction in Gels. Thesis, Stockholm, Sweden 1949.

Recommendations: Subcommittee on taxonomy of staphylococci and micrococci. Intern. Bull. Bacteriol. Nomen. Tax. 1965, 15, 109110.

Scheusner, D. L., L. L. Hood \& L. G. Harmon: Effect of temperature and $\mathrm{pH}$ on growth and enterotoxin production by Staphylococcus aureus. J. Milk Food Technol. 1973, 36, 249-252.

Untermann, $F$.: Contribution to the occurrence of enterotoxin producing staphylococci in man. Zbl. Bakt. Hyg. I. Abt. Orig. A. 1972, $222,18-26$.

Wadsworth, C.: A slide microtechnique for the analysis of immune precipitates in gel. Int. Arch. Allergy. 1957, 10, 355-360.

Vaughn, V. C.: Poisonous or sick cheese. Public. Health 1884, 10, 241245.

Zehren, V.L.\& V.F.Zehren: Examination of large quantities of cheese for staphylococcal enterotoxin A. J. Dairy Sci. 1968, 51, 635649. 


\section{SAMMANFATTNING}

Förekomst av enterotoxinproducerande stafylokocker $i$ näshåla, svalg och sårskador hos styckare.

Undersökningen omfattar 86 köttstyckare, som delades in i tre grupper - kliniskt friska, lätt förkylda samt individer med sårskador på händerna. I gruppen kliniskt friska hade $22 \%$ av individerna enterotoxinproducerande stafylokocker $i$ näshålan och $6 \%$ i svalget. I gruppen lätt förkylda var motsvarande förekomst $42 \%$ resp $12 \%$. Enterotoxinbildande stafylokocker isolerades från 4 av 16 undersökta „små-sår“. Merparten av de isolerade stammarna bildade enterotoxin A.

I artikeln diskuteras riskerna för kontaminering av livsmedel med enterotoxinproducerande stafylokocker samt riskerna för matförgiftningar.

(Received March 9, 1984).

Reprints may be requested from: M.-L. Danielsson, the Department of Food Hygiene, Faculty of Veterinary Medicine, Swedish University of Agricultural Sciences, S-750 07 Uppsala, Sweden. 